\title{
Wind power opportunities for remote mine sites in the Canadian North
}

\author{
S. Simard ${ }^{1}$, K. Fytas ${ }^{1}$, J. Paraszczak ${ }^{1}$, M. Laflamme ${ }^{1}$, and K. Agbossou ${ }^{2}$ \\ ${ }^{1}$ Department of Mining, Metallurgical and Materials Engineering \\ Laval University \\ 1065 av. de la Médecine, Quebec City, PQ, Canada, G1V 0A6 \\ Phone:+1 (418) 656-2131 \#5057, \\ e-mail: samuel.simard.3@ulaval.ca, Kostas.Fytas@gmn.ulaval.ca, \\ Jacek.Paraszczak@gmn.ulaval.ca, Marcel.Laflamme@gmn.ulaval.ca \\ ${ }^{2}$ Université du Québec à Trois-Rivières C.P. 500, 3351 boulevard des forges, Trois-Rivières, PQ, Canada, G9A 5H7 \\ Phone number : +1 (819) 376-5011 \#3911, e-mail : Kodjo.Agbossou@uqtr.ca
}

\begin{abstract}
High energy cost and high wind resource are creating an interest for wind-diesel hybrid power production for remote grids in the Canadian North. With the first industrial wind turbine in Nunavik, the Raglan Mine has demonstrated the benefits and viability of wind power as an economical way to produce fuel savings and environment benefits. Results for the first year of wind power production are presented. An after tax economic rate of return of $22,4 \%$ is calculated for the project. Financial analyses of adding multiple wind turbines to the remote grid are carried out, using Homer Pro and Retscreen 4 software. Lower economical returns are calculated for every wind turbine added to the grid. A fuel cost superior to $1 \mathrm{CAD} / \mathrm{L}$ is needed to achieved a minimal rate of return of $15 \%$, as the integration rate decreases for every additional wind turbine. Three energy storage options are evaluated in order to better utilise excess wind power. In presence of 2 or 3 wind turbines of $3 \mathrm{MW}$ nominal capacity each, a lithium-ion battery and a fly-wheel are financially the best energy storage technologies to increase the wind penetration. A hydrogen loop is calculated to be too expensive. An extreme high wind penetration rate, defined as 4 to 6 of the same wind turbine, is deemed not economically viable for the Raglan Mine, regardless of the energy storage technology considered.
\end{abstract}

\section{Key words}

Wind power. Wind-diesel hybrid. Energy storage. Return on investment. Remote grid.

\section{Introduction}

Mining industry is a substantial energy consumer, as a lot of energy is required to power mining and mineral processing equipment. As more and more mine operations move to remote locations, the access to reliable, secure and environmentally friendly energy sources becomes a key concern. At present, a great majority of remote mines in the Canadian North relies heavily on diesel fuel that has to be transported over long distances. In this context, some of the renewable energy sources especially wind power seems to provide a potentially interesting and viable alternative. More and more mines in the Canadian North are considering wind turbines as an auxiliary power source.

This paper analyses and discusses a case study of a nickel mine in the Canadian North that has successfully implemented the use of wind energy in order to save diesel fuel, to limit greenhouse gas emissions and decrease the reliance on conventional fuels and energy. 


\section{Methodology}

\section{A. Mine site configuration}

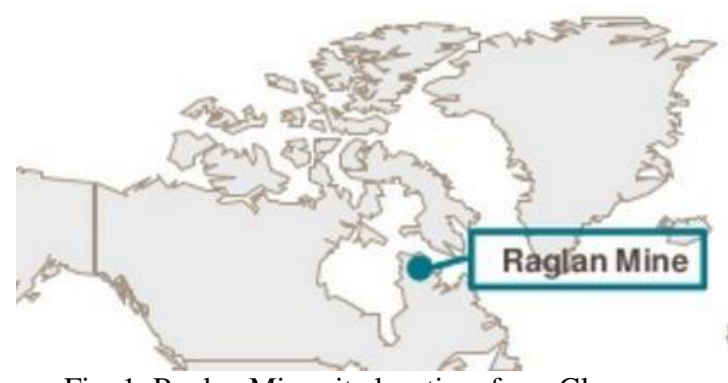

Fig. 1. Raglan Mine site location, from Glencore.

The Raglan remote nickel mine site located in the Canadian North was fully dependant on diesel fuel for power generation. The electric grid includes 6 base-load diesel generator sets of 3,6 MW and one of 4,4 MW, as well as 5 peak-load 1,8 MW sets. The newly added wind turbine and the energy storage systems are linked to the grid by a $25 \mathrm{KV}$ electric line, which links the main power house to the various mining sites. The supply side includes an energy intensive crusher, various electric equipment, lights and heaters which constitute a fairly continuous electric load during the day as presented on Fig. 2. On a yearly basis, the electric load is constant through the year with a small low for the 2 summer months. Monthly maximum, average and lows are presented on Fig. 3.

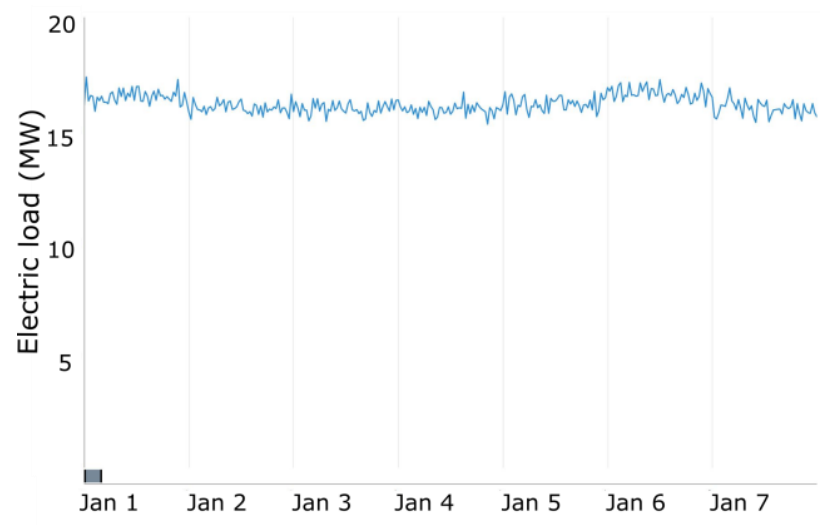

Fig. 2. Electric load variation for one week

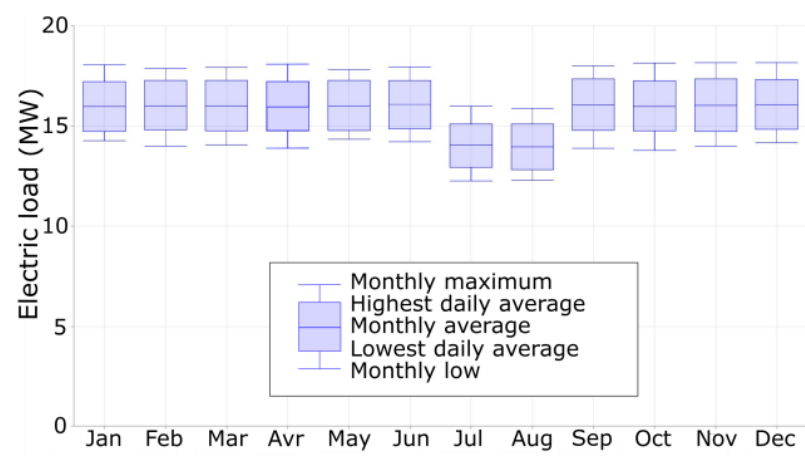

Fig. 3. Yearly electric load variation

\section{B. Wind resource assessment}

On-site real monitoring data were used for yearly wind pattern profile and other weather data. A ten minute average wind speed was calculated throughout the year and integrated into the calculation. Table 1. presents monthly wind speed averages and air temperatures, whereas Fig. 4. presents the wind speed cumulative frequency.

Table 1. - Montly wind speed and temperature averages

\begin{tabular}{lcc|lcc} 
& $\begin{array}{c}\text { Wind speed } \\
(\mathrm{m} / \mathrm{s})\end{array}$ & $\begin{array}{c}\mathrm{T} \\
\left({ }^{\circ} \mathrm{C}\right)\end{array}$ & & $\begin{array}{c}\text { Wind speed } \\
(\mathrm{m} / \mathrm{s})\end{array}$ & $\begin{array}{c}\mathrm{T} \\
\left({ }^{\circ} \mathrm{C}\right)\end{array}$ \\
Jan & 8.7 & -31.3 & Feb & 7.4 & -31.5 \\
\hline Mar & 9.3 & -23.6 & Apr & 9.2 & -11.6 \\
\hline May & 11.2 & -4.5 & Jun & 7.4 & 3.7 \\
\hline Jul & 9.2 & 9.9 & Aug & 8.1 & 7.5 \\
\hline Sep & 8.5 & 1.3 & Oct & 10.9 & -4.2 \\
\hline Nov & 7.9 & -14.3 & Dec & 11.4 & -20.9 \\
\hline Year & 9.13 & -10.9 & & &
\end{tabular}

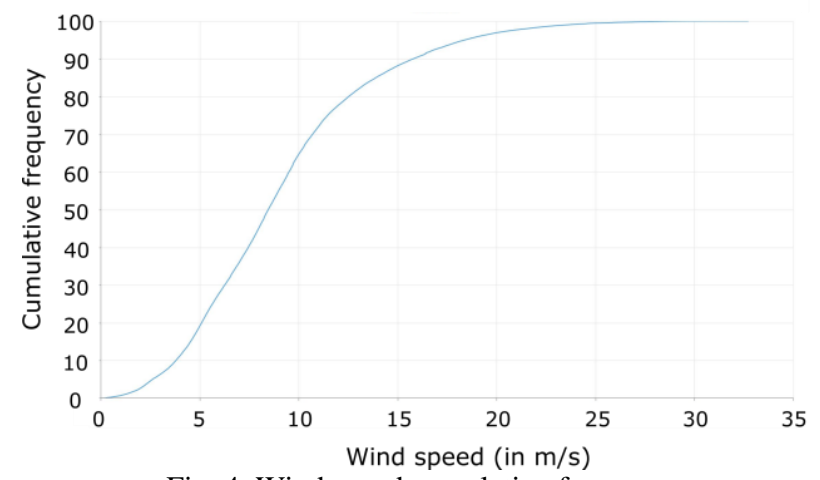

Fig. 4. Wind speed cumulative frequency

\section{Software used}

Two software were used for calculations. Homer Pro was used to calculate the technical performance of a single or multiples wind turbines at the Raglan mine electric grid [1], [2]. This software enables accurate calculation of the interaction between the multiple elements involved in the micro-grid. It also enables to use of yearly real time series for wind pattern, with a time step of 10 minutes, for the calculation presented here. The micro-grid configuration used for calculation is presented on Fig. 5. 


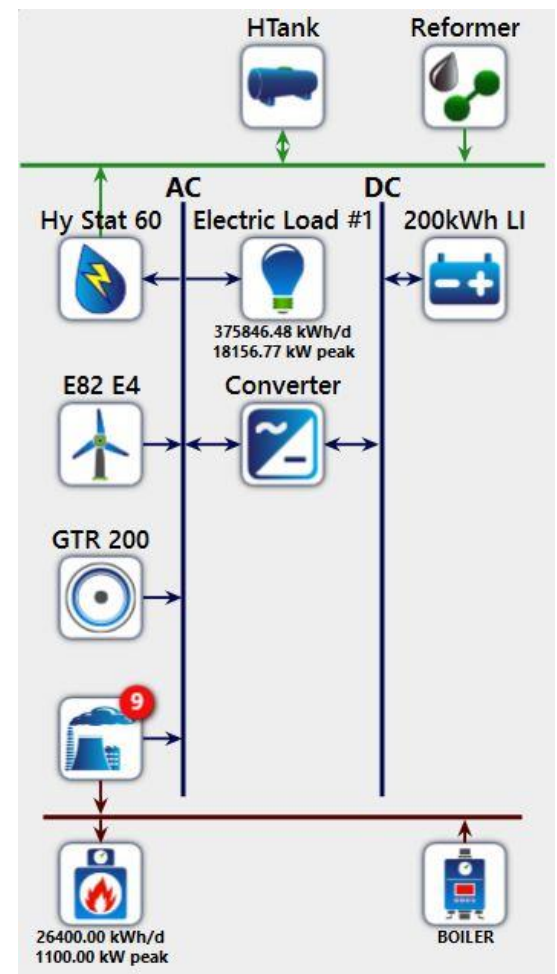

Fig. 5. Homer Pro grid model for Raglan Mine

RetScreen 4 [3] was used for financial calculations, such as return on investment and sensitivity analysis. Technical performance data used for these analyses was taken from the results of Homer Pro yearly calculations.

\section{Results for one wind turbine}

\section{A. Technical performance}

Located at Raglan Mine site, the first industrial wind turbine in Nunavik (Northern part of the province of Quebec) has produced a total of $8,3 \mathrm{GWh}$ in its first operational year. During the last six months of the year, the wind turbine was operated without a power limit thus allowing to project an annual performance of 9,4 GWh of integrated wind power. This energy represents annual fuel savings of 2,35 millions litres of diesel and 5600 tonnes of $\mathrm{CO}_{2}$ emissions avoided. The arctic environment has caused some technical difficulties, resulting in annual power losses of $0,21 \mathrm{GWh}$. The presence of strong winds in the area is however more than overcoming these challenges, allowing the wind turbine to perform at a $36 \%$ utilisation factor. See Fig. 6.

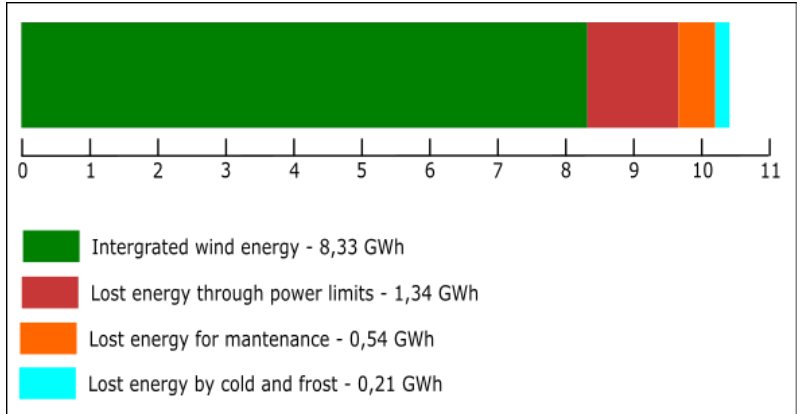

Fig. 6. Annual performance for the wind turbine inaugural year

\section{B. Economic performance}

According to the demonstrated performance of the wind turbine in the first year, the project's economic performance is calculated. An economic sensitivity analysis was carried out on the three main economic parameters of the project (Capex, Maintenance and Carbon credits), as well as three fuel cost scenarios: a first scenario with low price at: $0,50 \mathrm{CAD} / \mathrm{L}$, a median price of 1,00 CAD/L and a high price scenario at 1,50 $\mathrm{CAD} / \mathrm{L}$. Then, a $\pm 30 \%$ variation is applied to the Capex cost, while a $-30 \%$ to $+50 \%$ variation is applied to the maintenance cost and carbon market credits for the three fuel cost scenarios mentioned above. Results of the sensitivity analysis are found in Fig. 7, and economic parameter details are in Table 2. The fuel cost is demonstrated to be the factor with the highest influence on the economic performance of the project. A low fuel price enables a small economic return on the project, whereas with a high fuel cost high economic returns are realised for any Capex or maintenance cost increase. The median fuel cost scenario presents a $22,4 \%$ rate of return on investment, whereas a $12 \%$ increase in Capex cost would degrade the project below the $15 \%$ minimal rate of return acceptable for similar investment projects. A hypothetical carbon credit of 12,82 CAD/tonne of carbon avoided has a very low impact on the rate of return of the project. High fuel cost scenarios provide high rates of return on investment regardless variations of the other parameters.

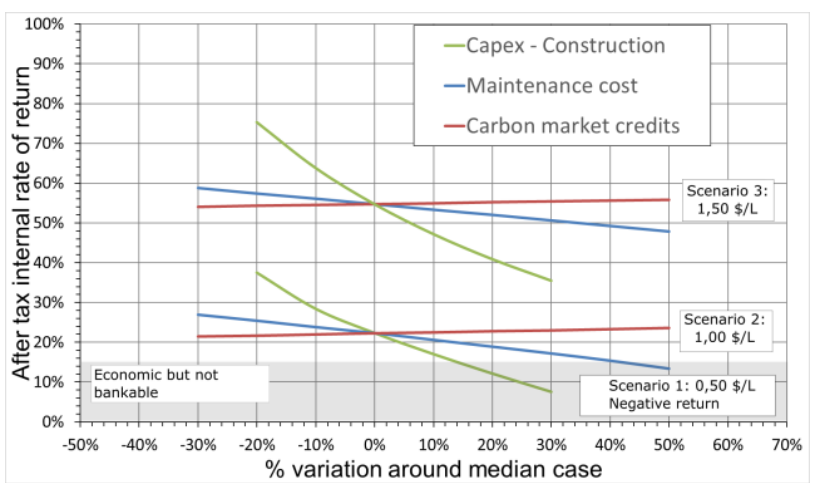

Fig. 7. Economic sensitivity analysis

Table 2. - Economic parameters

\begin{tabular}{l|c} 
& Cost (in CAD) \\
\hline $\begin{array}{l}\text { Total project cost including } \\
\text { energy storage }\end{array}$ & 22 million $\$$ \\
\hline Annual maintenance cost & $500000 \$$ \\
\hline Carbon credits & $12,82 \$ /$ ton \\
\hline Life of project & 20 years \\
\hline Fuel cost inflation & $2 \%$
\end{tabular}




\section{Results for multiple wind turbines}

Technical performance of the wind turbine is integrated in Homer Pro software in order to evaluate the performance of multiple wind turbines for this remote mine site. Low penetration cases correspond to 1,2 and 3 wind turbines identical to the currently installed one. Medium and high penetration cases correspond to $4,5,6$ wind turbines. Integration of wind power into a remote electric grid has to take into account several constraints which reduce the overall capacity of the grid to absorb wind power. These constraints include: diesel generator set minimal load ratio, minimal operating time and fuel consumption curve, as well as some grid stability issues regarding wind power variability and frequency control [4], [5]. As a result, the integration rate decreases from $97 \%$ with one wind turbine to $39 \%$ with 6 wind turbines. The results of the software calculations are presented in Fig 9. for a typical day when wind speed had grown from $6 \mathrm{~m} / \mathrm{s}$ to $10 \mathrm{~m} / \mathrm{s}$ as presented in Fig. 8.

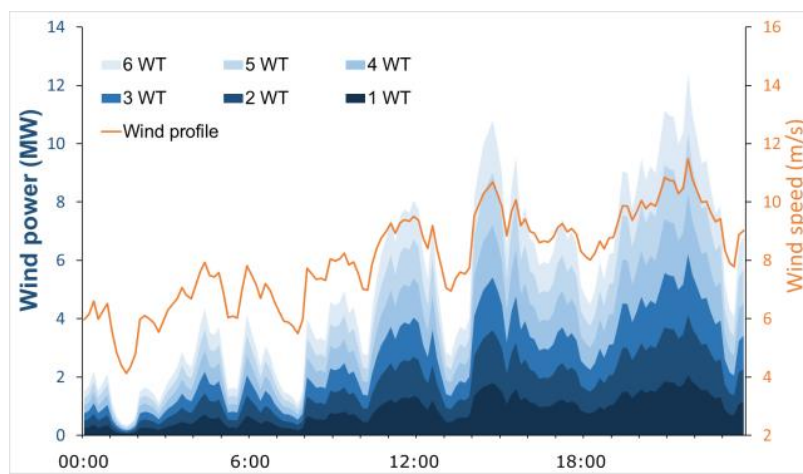

Fig. 8. Wind power for multiple wind turbines
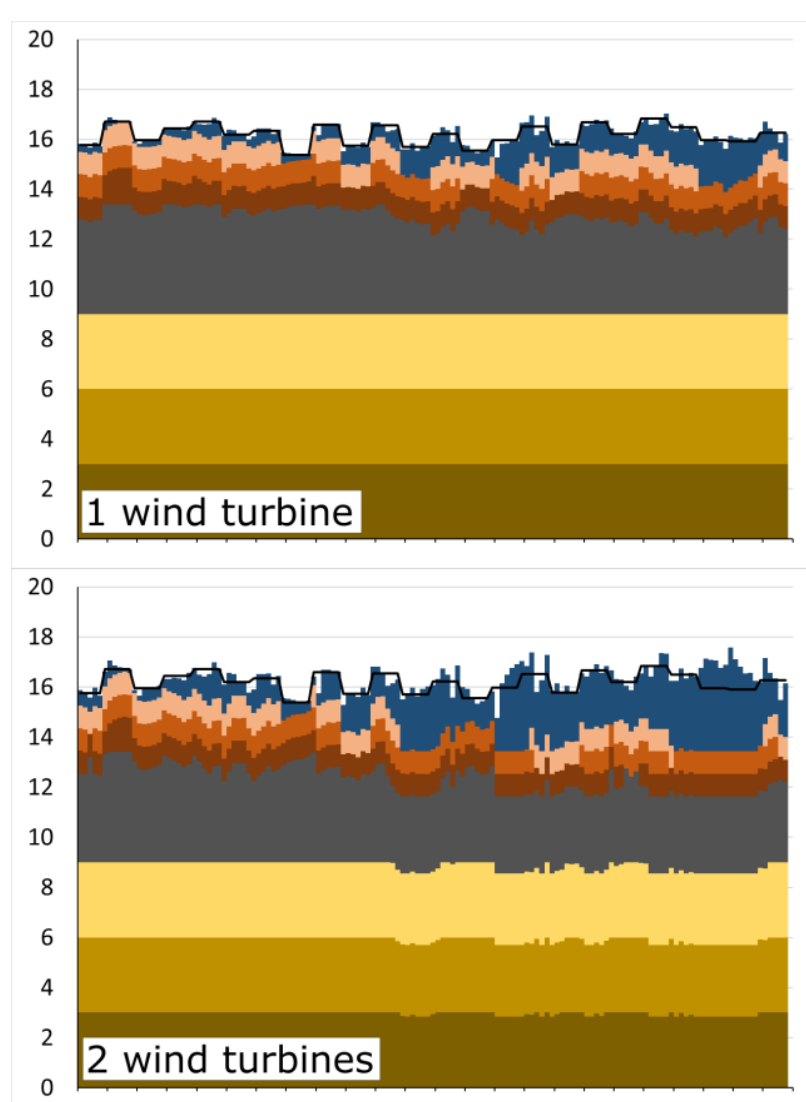
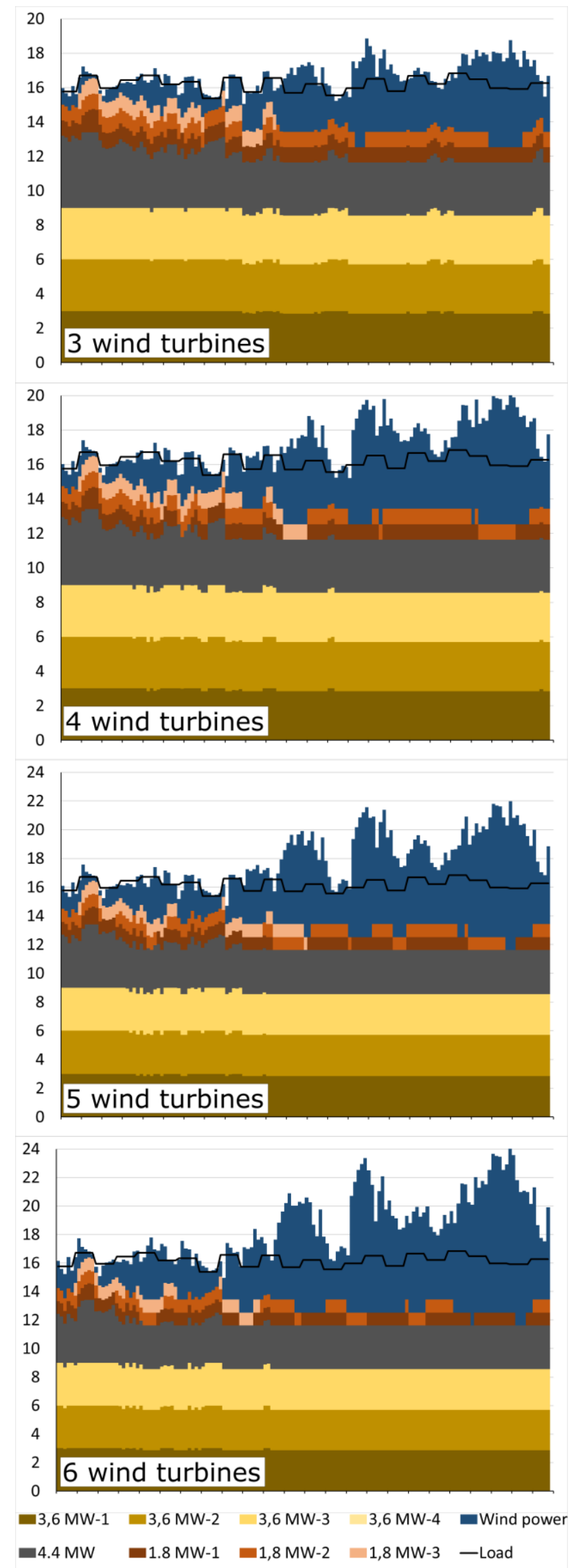

Fig. 9. Multiple wind turbines load integration in Raglan grid 
It is calculated that each additional wind turbine has a lower fuel saving performance, as its integration rate decreases. More specifically, it was observed a 2,35 ML of fuel savings for the first wind turbine versus only 5,76 ML in the case of 6 wind turbines. Of these, 1,24 ML are attributed to the second wind turbine, $0,81 \mathrm{ML}$ to the third one, 0,63 ML to the fourth one, 0,43 ML to the fifth one and only $0,30 \mathrm{ML}$ to the sixth one. Results are presented in Fig 10. below.

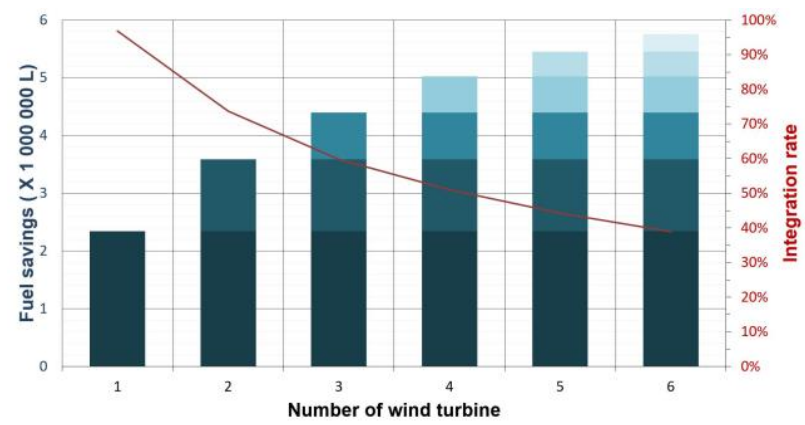

Fig. 10. Multiple wind turbines fuel savings

An economic analysis of multiple wind turbines, calculated with a median fuel price scenario of 1,00 $\mathrm{CAD} / \mathrm{L}$, gave the internal rates of return listed in Table 3. below. Every additional wind turbine is lowering the economic rate of the project. Fuel prices for which the project attains the minimum rate of return acceptable are presented in Table 3. and Fig. 11.

Table 3. - Multiple wind turbines economic results

\begin{tabular}{c|c|c}
$\begin{array}{c}\text { Number of } \\
\text { wind turbine }\end{array}$ & $\begin{array}{c}\text { Return rate as of } \\
1,00 \mathrm{CAD} / \mathrm{L}\end{array}$ & $\begin{array}{c}\text { Fuel price to attain } \\
15 \% \text { return rate }\end{array}$ \\
\hline 1 & $22,4 \%$ & $0,90 \mathrm{CAD} / \mathrm{L}$ \\
\hline 2 & $11,4 \%$ & $1,05 \mathrm{CAD} / \mathrm{L}$ \\
\hline 3 & $0,4 \%$ & $1,15 \mathrm{CAD} / \mathrm{L}$ \\
\hline 4 & Negative & $1,43 \mathrm{CAD} / \mathrm{L}$ \\
\hline 5 & Negative & $1,63 \mathrm{CAD} / \mathrm{L}$ \\
\hline 6 & Negative & $1,84 \mathrm{CAD} / \mathrm{L}$
\end{tabular}

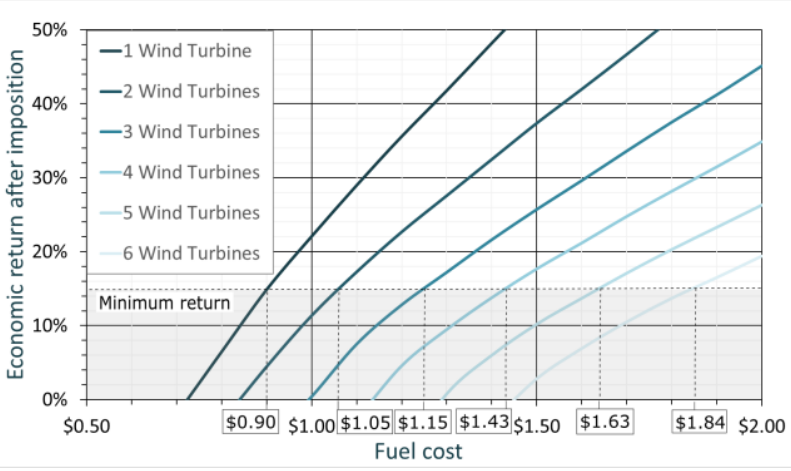

Fig. 11. Multiple wind turbines economic rates of return

\section{Results for energy storage}

Subsequently, the authors analysed the possibility of adding energy storage capacity to the remote electric grid in order to better integrate the electricity generated by the wind turbine [6], [7]. Three types of energy storage systems were analysed which are currently used as a demonstration at Raglan mine: a lithium-ion battery, a flywheel and a hydrogen loop [8] including an electrolyser and a fuel cell. Their performance measured as their ability to produce fuel savings was analysed in the presence of $1,2,3$ and 6 wind turbines. In the presence of one wind turbine, energy storage produces very little fuel savings as the wind power integration rate is high. In the presence of two or three wind turbines, some interesting fuel savings are achieved by the lithiumion battery and flywheel for storage power ratings lower than $20 \%$ of the winds turbines' rated power. Higher ratios of storage power to wind power were more expensive solutions than the diesel fuel saved. In the case of high wind penetrations, the economic value of battery storage decreases as fewer charging cycles are possible, considering the wind pattern of this site. The third evaluated option, the hydrogen loop was more expensive and not cost competitive with the diesel fuel savings. Fuel savings and KWh levelized prices are presented in Fig. 12. and Fig. 13. for the three technologies analysed.

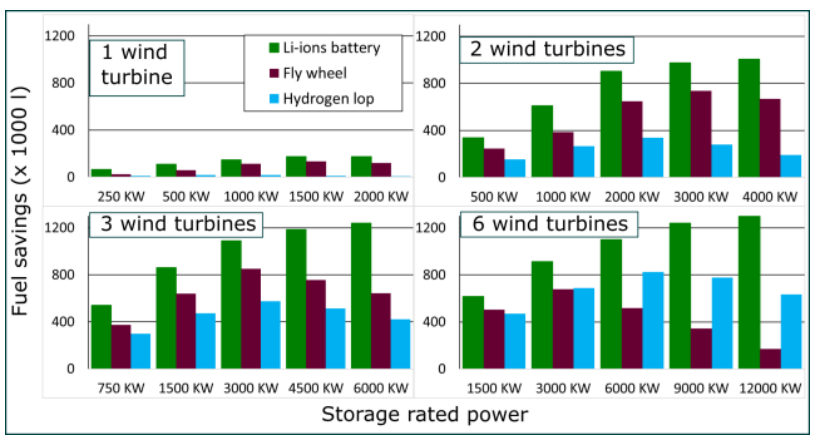

Fig. 12. Energy storage fuel savings

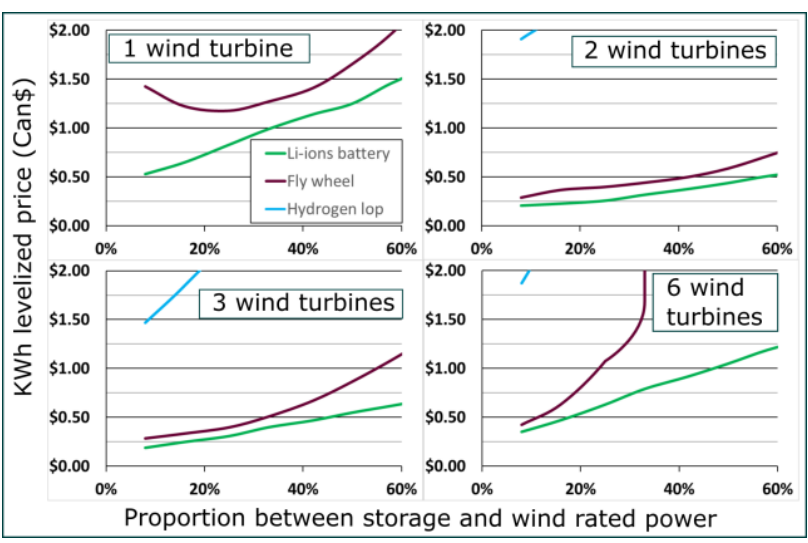

Fig. 13. Energy storage KWh price

For this mine site, energy storage by means of a lithiumion battery and a flywheel is an economic option that slightly enhances the wind penetration of the wind-diesel grid. A few hundred thousand extra litres of diesel fuel can be saved within a low penetration hybrid. Future reduction in energy storage cost could help similar hybrid grid to attain higher penetration rates. 


\section{Conclusion}

The first industrial wind turbine in Nunavik has demonstrated how adding wind power to a remote mine site within harsh winter conditions can produce significant fuel savings, as well as diversifying the mine fuel mix [9]. These fuel savings give positive economic returns on investment for small wind penetrations of 1 to 3 wind turbines of $3 \mathrm{MW}$ each but a fuel cost superior to $1 \mathrm{CAD} / \mathrm{L}$ would be necessary to justify higher penetration levels of 4 to 6 similar wind turbines. A lithium-ion battery combined with a flywheel provided the best economic scenario to store excess wind power, for a low ratio of energy storage versus wind power nominal rate. At the Raglan Mine site, this study concludes that a high wind power penetration rate beyond 3 wind turbines would be uneconomical under the scenarios considered. A future study may address the potential of using a diesel generator set able to produce electricity at low load ratios as a running operating reserve potentially delivering more fuel savings at high penetration than the energy storage options evaluated.

Low penetration wind power has been demonstrated as a reliable, economic low carbon fuel source for electricity generation on remote mine sites. Lessons learned at the Raglan Mine site are useful for other similar remote grids operating in Northern Canada and other sites with high wind resources and scarce solar potential. These sites include remote communities [10]-[13], and industrial sites where all electricity needs are provided by diesel generators. Renewable sources, mostly wind power, integrated into a higher power price environment give opportunities for some significant cost savings and environmental benefits. The next challenge to overcome is to bridge the gap between the financial terms of a renewable energy project and the quarterly financial results of a mining company, until carbon pricing policies become more predominant in the levelized cost of diesel electricity generation in the North and until diesel subsidies recede.

\section{Acknowledgement}

The authors would like to thank Tugliq Energy Co. for its financial support during this research project and for generously providing data. The project was also financed by a grant by the National Science and Engineering Research Council of Canada (NSERC).

"The conclusions and results presented herein are solely those of the author(s) and do not engage Tugliq Energy nor its partners, customers, suppliers, financiers, and sponsors."

\section{References}

[1] N.A.A. Razak, M.M. Othman and I. Musirin, "Optimal Sizing and Operational Strategy of Hybrid Renewable Energy System Using HOMER", $4^{\text {th }}$ International Power Engineering and Optimization Conference in Malaysia, (2010), 7 p.

[2] F. Katiraeai and C. Abbey, "Diesel Plant Sizing and Performance Analysis of a Remote Wind-Diesel Microgrid", IEEE-PES General Meeting, (2007), 12 p.

[3] Natural Resources Canada, "Analyse de projets de centrales éolienne", RETScreen International CANMET, (2004), 30 p.

[4] M.R. Patel, "Wind and solar power systems: design, analysis, and operation", CRC press, (2012), 448 p.

[5] M. Miligan, P. Donohoo, D. Lew, E. Ela and B. Kirby, "Operating Reserves and Wind Power Integration: An International Comparison", NREL Conference Paper, (2010), $19 \mathrm{p}$.

[6] M. Beaudin, H. Schellenberglade and W. Rosehart, "Energy storage for mitigating the variability of renewable electricity sources: An updated review", in Energy for Sustainable Development, (2010), 13 p.

[7] T.M. Weis and A. Illinca, "The utility of energy storage to improve the economics of wind-diesel power plants in Canada", Renewable Energy, vol. 33, (2008), 1544-1557 p.

[8] E. Bernier, J. Hamelin, K. Agbossou and T. K. Bose, "Electric round-trip efficiency of hydrogen and oxygen-based energy storage", International Journal of Hydrogen Energy, (2005), $7 \mathrm{p}$

[9] R. Lydan, "Energy Diversification for Mining", Renewable Energy for Mining conference in Toronto, Hatch, (2013), 20 p.

[10] M. Arriaga Martin, "Long-Term Renewable Energy Electricity Planning for Remote Communities", $\mathrm{PhD}$ thesis, Waterloo University, Waterloo (2015), 135 p.

[11] J.-C. Deslauriers and J. Fontaine, "Le plan d'approvisionnement 2008-2017 des réseaux autonomes d'Hydro-Québec Distribution", Régie de l'énergie, (2008), 56 p.

[12] Québec Government, "Politique énergétique, L'énergie des Québécois, Source de croissance", Québec Governement, (2016), 66 p.

[13] T.M. Weis, P. Eng and J. Maissan, "Assessing the Potential Uptake for a Remote Cummunity Wind Incentive Program in Canada", Pembina Institute, (2007), 27 p. 